\title{
画像解析の手法を用いたホルスタイン種去勢牛における 牛肉の締まりの客観的評価法の検討
}

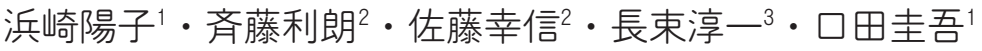 \\ 1 帯広畜産大学, 帯広市 $080-8555$ \\ 2 北海道立畜産試験場, 北海道新得町 $081-0038$ \\ ${ }^{3}$ ホクレン畜産技術研究所, 北海道訓子府町 099-1421
}

(2008. 5. 9 受付, 2008. 10. 10 受理)

\begin{abstract}
要 約肉の締まりは, 肉の品質に深く関係しており, 枝肉の経済的価值に与える影響も大きい.し かし, 判定基準となる標準模型はなく, 肉眼による安定した評価が困難な項目といわれている. 本研究 では，画像解析による肉の締まりの客観的評価法を検討することを目的とした．材料牛として，ホルス タイン種去勢牛 51 頭を用いた。肉の締まりについては 15 段階の詳細な肉眼的評価を行い，その評価值 を分析に用いた。また，画像解析により，ロース芯の脂肪面積割合と脂肪交雑粒子の特徵を示す形質お よび僧帽筋の筋束間隙割合と筋束間隙の特徵を示す形質を算出した．肉の締まりの詳細評価値を従属変 数，画像解析形質を独立変数候補とした重回帰分析を行った結果，選択された形質は僧帽筋の筋束間隙 割合（回帰係数の符号：一）およびロース芯の脂肪面積割合 $(+)$ であった $\left(R^{2}=0.71, P<0.01\right)$. 本 研究の結果, 僧帽筋の筋束の状態は肉の締まりと関連性が高いことが示され，画像解析による肉の締ま りの客観的評価の可能性が示唆された.
\end{abstract}

日本畜産学会報 80 (1), 47-54, 2009

牛枝肉の肉質評価項目は, 「脂肪交雑」,「肉の色沢」, 「肉の締まりおよびきめ」および「脂肪の色沢と質」の 4 項目において評価される.4 項目は各々5 段階に格付け され，4 項目の中で最も低い等級が肉質等級として判定 される. わが国では，脂肪交雑の程度の高い牛肉が市場 において好まれており，脂肪交雑が優れていると経済的 価值が高くなる傾向にある. しかしながら, 前述の通り, 脂肪交雑の評価値が高くても, その他の 3 項目の評価値 次第では，肉質等級が格下げになる，脂肪交雑の評価値 に対して肉質等級が格下げになる主な要因として，肉の 締まりおよびきめ等級が他の項目よりも劣ることが挙げ られる.肉の締まりおよびきめ等級についての格付記録 が入手できた黒毛和種のデー夕を例に挙げると，2005 年 4 月から 2007 年 9 月に北海道の枝肉市場に出荷された 黒毛和種の枝肉格付記録 $(n=4,271)$ において, 脂肪交 雑の評価より肉質等級が格下げになった枝肉が $23.3 \%$ ( $\mathrm{n}=995)$ あり，この内，肉の締まりおよびきめ等級が 原因で格下げになったものが $93.8 \%(n=933)$ を占め ていた。肉の締まりおよびきめ等級は，「締まり」と「き め」の各々5 段階の評価が行われ, 2 項目のうち, 低く評
価された值が等級として判定されるが，前述の 933 頭の うち，「きめ」に対して「締まり」の評価値が低い枝肉が

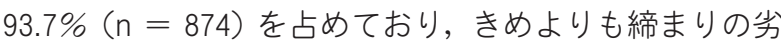
る枝肉が多く存在し，それが原因で格付が低く評価され ている，また，肉の締まりは，食肉の保水性と深く関連 しており，締まりが悪い肉は食肉としての見た目も悪 く，肉汁を損失するため重量が減りかつ味も低下する （中央畜産会 2000）ともいわれていることから，牛肉の 経済的価值に対して少なからず影響を与えていると推察 される.

われわれの研究グループは，これまでに画像解析の手 法を用いて, 脂肪交雑（長谷川ら 2004 ; 浜崎ら 2005）お よび肉色（高橋ら 2006）の客観的評価を実施し，それら について，高い精度での評価が可能であると報告した。 肉の締まりの肉眼による評価には熟練が必要であるとい われており，画像解析の手法を応用することによって， 肉の締まりを客観的かつ安定的に評価できれば，格付時 の補助データとして有用であると考えられる。また，木 ルスタイン種のような乳用種においては，ほとんどの枝 肉が肉の締まりの評価値は 2 と格付されているものの，

連絡者： $\square \boxplus$ 圭吾（fax:0155-49-5462,e-mail : kuchida@obihiro.ac.jp） 
実際は, 同じ評価値 2 であっても, 評価値 3 に近いもの から評価値 1 に近いものと, その肉の締まりの状態には 幅があると考えられる. 客観的評価により, 肉の締まり について詳細な評価値を算出できれば，現行の格付では 肉の締まりの評価に差が生じない品種において, 経済的 価値の判断材料として有用となる.

肉の締まりは, 骨格筋の切断面において水分が浮き上 がっていない状態を「良い, 肉汁が滲出している状態を 「悪い」亡評価される (沖谷 1996). 本研究では, 牛枝肉 の第 6-7 肋骨間の僧帽筋断面において, 筋束間の境界線 (以下, 筋束間隙) が目視できるものや, その筋束間隙に ドリップが見られる枝肉があることに着目し, 僧帽筋に おける筋束間隙の状態に関する画像解析を行い, 肉の締 まりの客観的評価の可能性について検討した.

\section{材料および方法}

本研究では, 材料牛として 2006 年 8 月から 10 月に北 海道内の枝肉処理施設において屠畜解体されたホルス夕 イン種去勢牛 51 頭を用いた。第 6-7 肋骨間における枝 肉横断面高精細画像の撮影および肉の締まりの詳細評価 については，枝肉処理施設において，屠畜 2 日後に日本 食肉格付協会による格付とほぼ同時刻に行った。撮影に は, 牛枝肉専用撮影装置であるミラ一型撮影装置 (HK333 ; 早坂理工，札幌）を用いた。肉の締まりについて は, 日本食肉格付協会の格付員が行う通常の枝肉格付で は1等級（劣るもの）から 5 等級（かなり良い）の 5 段 階評価が行われる (以下, 締まり格付評価値) が, 本研 究では, 肉質評価に熟練したセり業務担当者一名によっ て，例えば格付の 2 等級を，2-，2，2+のように3 段階 に分類することで, 計 15 段階に細分化した第 6-7 肋骨 間断面における肉の締まりの詳細な評価値（以下，締ま り詳細評価値）を得た。なお, 調査期間中における肉の 締まりの詳細評価については, すべて同一の評価者に よって行われた. また, 屠畜から 7 11日間, $0^{\circ} \mathrm{C}$ に設定 された枝肉用冷蔵庫で保存した後, 第 7-10肋骨間のリ ブロースを切り出し, 設定温度 $15^{\circ} \mathrm{C}$ の実験室内におい て, 僧帽筋のズーム画像の撮影を行った。撮影には, ウ ルトラマクロレンズ (LZ3-2 ; GOKO, 神奈川) を装着し たデジタルカメラ (D70 ; ニコン, 東京)を用いた. 本研 究で用いたウルトラマクロレンズは, 白色 LED を内部 に18 個配置しており, 外部光の影響を受けずに接写撮 影が可能である. カメラは実験台の上で上下のスライド が可能なスタンドに設置し, 焦点距離を微調整しなが ら, 左半丸の第 6-7 肋骨間における僧帽筋ズーム画像を 撮影した。 なお，肉の締まりの客観的評価法を検討する にあたって, 枝肉の経済的価値に最も影響を与えるロー ス芯を調査対象亡するのが適切であると考えられるが, ウルトラマクロレンズでロース芯のズーム画像を撮影し たところ，ロース芯のきめは繊細で，その切断面は非常
に滑らかであり，画像解析によって肉の締まりに関連が あると推察されるドリップや筋束の状態に関する形質を 算出するには適さなかった。 そのため, 調查対象を僧帽 筋とした.

\section{1. ロース芯における画像解析形質の算出}

ミラー型撮影装置により得られた第 6-7 肋骨間枝肉横 断面画像から画像解析形質を算出するために, 牛枝肉画 像解析ソフトウェア (BeefAnalyzer II ; 早坂理工) を用 いた。まず，枝肉横断面画像から口ース芯を抽出するた めに, 自動的にロース芯の輪郭線を描画し, 輪郭が誤認 識された部分については，手動による補正を行った。抽 出したロース芯の画像を用いて，ロース芯面積，ロース 芯内に占める脂肪交雑の割合 (以下, 脂肪面積割合), 全 体のあらさ指数, 最大粒子のあらさ指数, 脂肪交雑粒子 数, 上位 1 5 のあらさ指数, 上位 1 10 のあらさ指数, 指定範囲内脂肪交雑粒子数および細かさ指数の計 9 形質 を算出した。画像解析により脂肪交雑のあらさを評価す るための手法として，2 値化した脂肪交雑粒子の面積を 用いた例（白仁田ら 1996）があるが，実際には脂肪交雑 粒子同士が接触しており，視覚的には小さな脂肪交雑粒 子が多数あるように認識されたとしても，画像解析では 1 つの脂肪交雑粒子に認識される場合がある. そこで, 各口ース芯内の脂肪交雑粒子の特徵を表すために，2 值 化画像に対して細線化処理を施し, 個々の脂肪交雑粒子 を独立させ，評価した。なお，ホルスタイン種の画像解 析による BMS ナンバーの推定法について報告した浜崎 ら（2005）の結果から，本研究における細線化処理の回 数は 5 回とした.

脂肪面積割合は 2 値化後の画像を用いてロース芯内に 脂肪交雑粒子が占める割合を算出した。 全体のあらさ指 数, 最大粒子のあらさ指数および脂肪交雑粒子数は,

円ら（1997，2002）が考案した手法により算出した. 全 体のあらさ指数の值が高い場合は，ロース芯内にあらい 脂肪交雑粒子が多く存在することを示しており, 最大粒 子のあらさ指数の值が高い場合は，ロース芯内に単独で 大きな脂肪交雑粒子が存在することを示している. ま た，全体のあらさ指数は脂肪面積割合に影響されてお り, 視覚的に脂肪交雑粒子のあらさに即していない場合 があるため, 高橋ら（2006）が考案した，個々の脂肪交 雑粒子を面積の大きい順に並び替え，もっとも大きい脂 肪交雑粒子からそれぞれ 5 番目および 10 番目までの脂 肪交雑粒子面積を加算したときの脂肪交雑のあらさ（上 位 1〜 5 のあらさ指数および上位 1 ～10 のあらさ指数） を算出した。また， ロ田ら（2006）の手法を用いて，指 定範囲 $\left(0.01 \sim 0.5 \mathrm{~cm}^{2}\right)$ の脂肪交雑粒子の数（指定範囲 内粒子数)および細かさ指数を算出した. 細かさ指数と は指定範囲内の脂肪交雑粒子数をロース芯面積で除した 値であり，值が大きいほど，ロース芯内に細かい脂肪交 雑粒子が多く存在することを表す。 


\section{2. 僧帽筋の筋束間隙に関する画像解析形質の算出}

ウルトラマクロレンズによって撮影した僧帽筋ズーム 画像 $(3008 \times 2000$ 画素) 全体を分析対象領域とし，画像 処理には，画像編集アプリケーションであるPhotoshop CS2 (Adobe, 東京) を用いた. 本研究では, 僧帽筋ズ一 厶画像 (図 1-a) において, 目視できる筋束間の境界部分 (筋膜や, 筋束が隆起して出来た筋束間の溝) を筋束間隙 と定め，筋束間隙部分全体を手動で塗りつぶし（図 1b), その画素数を計測した。 なお， ミラ一型撮影装置に より撮影したロース芯断面の画像において，目視できる 筋束間隙がほとんど存在しないのに対して, ウルトラマ クロレンズを用いて撮影した僧帽筋ズーム画像において は，大小さまざまな筋束間隙を目視により確認すること が可能であった。

僧帽筋の筋束間隙に関する画像解析形質として，筋束 間陌の画素数を分析対象領域の画素数で除した値を筋束 間隙割合として算出した。なお，分析対象領域内に皮下 脂肪や筋間脂肪が含まれていた場合は，その領域を分析 対象から除外した。さらに，筋束間隙を描画した画像を 用いて，前述のロース芯内の脂肪交雑粒子に関する形質 の場合と同様に，BeefAnalyzer ||により筋束間隙の特徵 を表す形質を算出した. その結果, 筋束間隙に関する画 像解析形質として, 筋束間隙割合, 筋束間隙のあらさ指
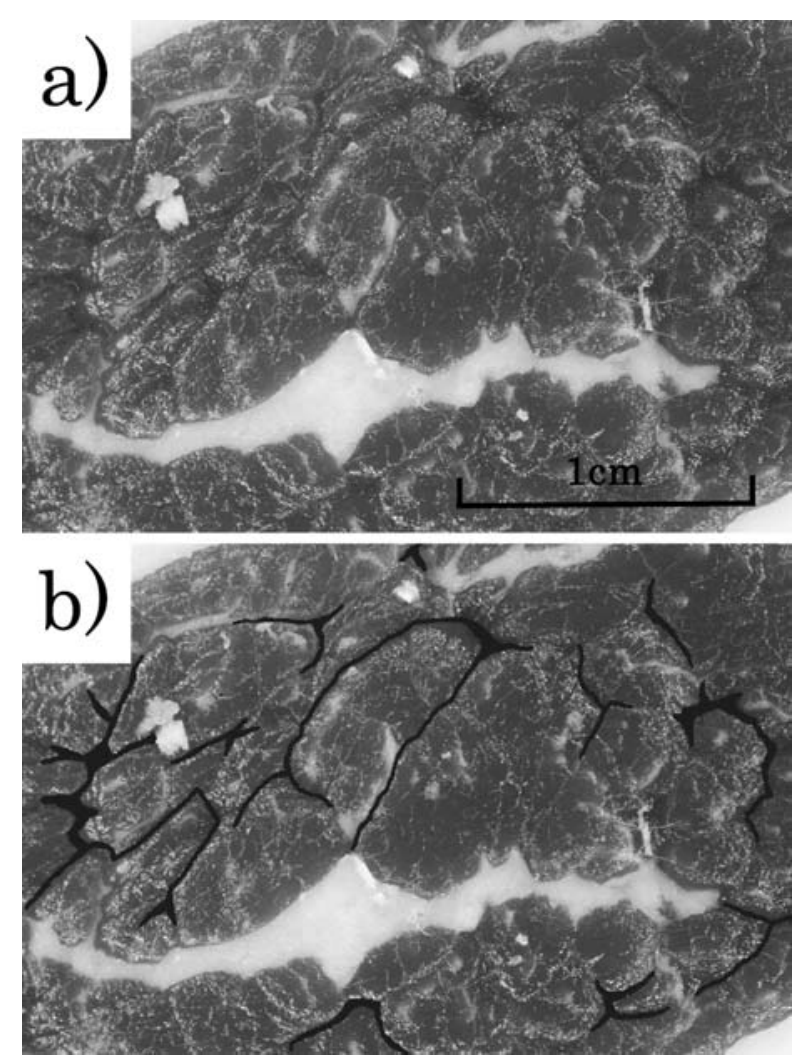

Figure 1 Original (a) and processed (b) digital images of the M. trapezius taking with an ultra macroscopic lens.
数，筋束間隙の最大あらさ指数，筋束間隙数，筋束間隙 の上位 1〜 5 のあらさ指数および上位 1〜10 のあらさ指 数，指定範囲内 $\left(0.01 \sim 0.5 \mathrm{~cm}^{2}\right)$ の筋束間隙数および筋 束間陌の細かさ指数の計 8 形質を算出した. なお, 細線 化処理の回数は 5 回とした.

以上のデー夕を用いて, 肉の締まりの詳細評価値と画 像解析形質の関連性の調査を行った。また肉の締まりの 詳細評価値を従属変数, 画像解析形質を説明変数候補と して重回帰分析を行った。変数選択法には最大 $R^{2}$ 法を 用い，選択される変数は 3 変数以内に制限した。第 6-7 肋骨間における枝肉横断面画像から得たロース芯におけ る画像解析形質 (9 変数) のみを説明変数候補として用 いた場合と, ロース芯における画像解析形質 (9 変数)に 加えて, 僧帽筋ズ一ム画像から得た筋束間隙に関する画 像解析形質 (8 変数) を用いた場合における重回帰分析 を行い，画像解析による締まりの客観的評価の推定精度 の違いについて調査した. なお, 統計処理にはSAS (SAS Institute Inc., 1985) の CORR および GLM プロシ ジャを用いた。

\section{結果および考察}

\section{1. 基礎統計量}

格付形質および画像解析形質の基礎統計量を表 1 に示 した。材料牛における屠畜月齢, 枝肉重量, BMS ナン バーおよびロース芯の脂肪面積割合の平均値および標準 偏差はそれぞれ，20.90 土0.41 力月齢， $469.73 \pm 36.55$ $\mathrm{kg}, 2.16 \pm 0.37$ およひ $20.43 \pm 4.39 \%$ であった. 本研 究と同地域において, ホルスタイン種去勢牛の調査を 行った浜崎ら（2005）は, 枝肉重量, BMS ナンバーおよ びロース芯の脂肪面積割合の平均および標準偏差につい て，それぞれ，469.76 土26.31 kg, $2.31 \pm 0.59$ おび $18.09 \pm 4.17 \%$ と報告している。枝肉重量およびBMS ナンバーについては同程度であったが，脂肪面積割合に ついては本研究においてやや高い値を示した。また日本 食肉格付協会が公表している牛枝肉格付情報（日本食肉 格付協会 2007) において，平成 18 年度（平成 18 年 4 月 〜平成 19 年 3 月）に出荷された乳用種去勢牛の枝肉重 量, BMS ナンバーおよび肉の締まりおよびきめ等級の 全国平均 (調査頭数) は 424.1 kg ( $n=52,644), 2.1$ ( $n$ $=51,062)$ および2.1（ $n=51,062 ）$ であった. 枝肉重量 については, 本研究の材料牛と比較してかなり小さい値 であったが，BMSナンバーおよび肉の締まりおよびき め等級では同程度であった。また，肉の締まりおよびき め等級の分布については，本研究の材料牛で等級 2 (84.8\%) および等級 3(12.3\%)，全国における結果（n =51,062) では，等級 $2(94.1 \%)$ および等級 3（5.9\%） であり，肉の締まりおよびきめ等級が 2 と評価される枝 肉が多い傾向は一致していた。表 2 に本研究の材料牛の 締まり格付評価値と締まり詳細評価値の分布を示した. 
浜崎・斉藤・佐藤・長束 $\cdot \square \boxplus$

Table 1 Carcass and image analysis traits of Holstein steers $(n=51)$

\begin{tabular}{|c|c|c|c|c|}
\hline Traits & Mean & SD & Min & Max \\
\hline \multicolumn{5}{|l|}{ Carcass traits } \\
\hline Slaugher age (month) & 20.90 & 0.41 & 20.16 & 21.70 \\
\hline Carcass weight (kg) & 469.73 & 36.55 & 377.00 & 544.00 \\
\hline Rib eye area $\left(\mathrm{cm}^{2}\right)$ & 46.06 & 5.48 & 37.00 & 60.00 \\
\hline Rib thickness (cm) & 5.95 & 0.72 & 4.30 & 7.70 \\
\hline Subcutaneous fat thickness $(\mathrm{cm})$ & 2.05 & 0.69 & 1.00 & 4.60 \\
\hline Yield score & 69.64 & 0.94 & 66.90 & 71.50 \\
\hline BMS No. $(1 \text { to } 12)^{a}$ & 2.16 & 0.37 & 2.00 & 3.00 \\
\hline Meat firmness ( 1 to 5 ) & 2.06 & 0.24 & 2.00 & 3.00 \\
\hline Meat firmness and texture grade ( 1 to 5 ) & 2.06 & 0.24 & 2.00 & 3.00 \\
\hline $\mathrm{DSMF}^{\mathrm{b}}$ & 1.98 & 0.31 & 1.33 & 2.67 \\
\hline \multicolumn{5}{|l|}{ Image analysis traits } \\
\hline GAPPER $(\%)^{\mathrm{C}}$ & 5.62 & 2.27 & 2.53 & 10.49 \\
\hline Rib eye area $\left(\mathrm{cm}^{2}\right)$ & 47.01 & 6.53 & 27.13 & 62.72 \\
\hline FATPER $(\%)^{d}$ & 20.43 & 4.39 & 12.56 & 32.77 \\
\hline
\end{tabular}

aMSNo. ; beef marbring standard number.

${ }^{b}$ DSMF ; detailed evaluation score of meat firmness.

${ }^{\circ}$ GAPPER ; ratio of gap of the muscle bundles in the object region ( $3008 \times 2000$ pixels) on M. trapezius.

${ }^{\mathrm{d}}$ FATPER ; ratio of marbling area to rib eye area.

Table 2 Frequency of grading score and detailed evaluation score of meat firmness for Holstein steers $(n=51)$

\begin{tabular}{cccc}
\hline \hline \multirow{2}{*}{$\begin{array}{c}\text { Score of } \begin{array}{c}\text { meat } \\
\text { firmness }\end{array} \\
\end{array}$} & Grading score ${ }^{\mathrm{a}}$ & & DSMF $^{\mathrm{b}}$ \\
3 & $3(5.88 \%)$ & & $1(1.96 \%)$ \\
$3-$ & - & & $1(1.96 \%)$ \\
$2+$ & - & & $14(27.45 \%)$ \\
2 & $48(94.12 \%)$ & & $21(41.18 \%)$ \\
$2-$ & - & & $11(21.57 \%)$ \\
$1+$ & - & & $4(7.84 \%)$ \\
\hline
\end{tabular}

${ }^{a}$ Grading score ; Meat firmness score was graded by a meat grader.

${ }^{\mathrm{b}}$ DSMF ; detailed evaluation score of meat firmness.

\section{2. 画像解析形質亡肉の締まりとの関連性}

1）ロース芯内の脂肪交雑と肉の締まりとの関連性

ロース芯における画像解析形質と肉の締まりの詳細評 価値との相関係数を表 3 に示した。ロース芯面積および ロース芯の最大粒子のあらさ指数以外のロース芯の画像 解析形質において，いずれも肉の締まり詳細評価値と有 意な相関が見られた。最も強い相関を示したのはロース 芯の脂肪面積割合であり，その相関係数は $0.73(P<$
0.01)であり，これは，ロース芯内に多く脂肪交雑が含ま れているほど, 肉の締まり詳細評価値が高くなることを 示している. 脂肪交雑の程度の高い肉では, 骨格筋内の 筋束間脂肪細胞に脂肪が蓄積しているため, 保水性が高 く，また締まりも良いと言われており，本研究において も同様の傾向が見られた。 またロース芯の最大粒子のあ らさ指数を除く脂肪交雑粒子のあらさに関する 4 形質 において 0.32 から 0.48 の中程度の相関を示した $(P<$ $0.01 \sim 0.05)$. 脂肪交雑粒子の細かさを示す 2 形質につい ても 0.50 および 0.57 と正の相関を示した $(P<0.01)$ ことから, 本研究で用いたホルスタイン種においては, 脂肪交雑粒子のあらさや細かさに関わらず，ロース芯内 に脂肪交雑が多く存在することにより締まりの評価値も 高くなることが示唆された。

2）僧帽筋の筋束間隙に関する画像解析形質と肉の締 まりとの関連性

僧帽筋における筋束間隙に関する画像解析形質と肉の 締まりの詳細評価値との相関係数を表 4 に示した. 僧帽 筋における筋束間隙に関する画像解析形質のうち, 締ま り詳細評価値と最も強い相関を示したのは，筋束間隙割 合であり，その相関係数は-0.75 $(P<0.01)$ であった. これは，僧帽筋の切断面において目視できる筋束間隙が 少ないほど肉の締まりが良いことを示している。締まり 詳細評価値との間に, 筋束間隙のあらさに関する画像解 
Table 3 Correlation coefficients among image analysis traits of rib eye and detailed evaluation scores of meat firmness

\begin{tabular}{|c|c|c|c|c|c|c|c|c|c|}
\hline Traits & DSMFa $^{\mathrm{a}}$ & $\begin{array}{l}\text { Rib eye } \\
\text { area }\end{array}$ & FATPER & $\begin{array}{l}\text { O_COARSE } \\
\text { of rib eye }\end{array}$ & $\begin{array}{l}\text { N_COARSE } \\
\text { of rib eye }\end{array}$ & $\begin{array}{l}\text { COARSE 1-5 } \\
\text { of rib eye }\end{array}$ & $\begin{array}{l}\text { COARSE 1-10 } \\
\text { of rib eye }\end{array}$ & $\begin{array}{c}\text { M_COARSE } \\
\text { of rib eye }\end{array}$ & $\begin{array}{l}\text { NSF of } \\
\text { rib eye }\end{array}$ \\
\hline Rib eye area & 0.09 & & & & & & & & \\
\hline FATPER ${ }^{b}$ & $0.73^{* *}$ & -0.03 & & & & & & & \\
\hline O_COARSE of rib eye ${ }^{c}$ & $0.46^{* *}$ & -0.01 & $0.55^{* *}$ & & & & & & \\
\hline N_COARSE of rib eye ${ }^{d}$ & $0.48^{* *}$ & $0.33^{*}$ & $0.68 * *$ & -0.01 & & & & & \\
\hline COARSE $1-5$ of rib eye $e^{e}$ & $0.32^{*}$ & -0.05 & $0.41^{* *}$ & $0.93^{* *}$ & -0.19 & & & & \\
\hline COARSE $1-10$ of rib eye ${ }^{f}$ & $0.35^{*}$ & -0.06 & $0.42^{* \star}$ & $0.96^{* *}$ & -0.19 & $0.99 * *$ & & & \\
\hline M_COARSE of rib eye ${ }^{g}$ & 0.23 & -0.05 & $0.38^{* *}$ & $0.79 * *$ & -0.17 & $0.91^{* *}$ & $0.86^{* *}$ & & \\
\hline NSF of rib eye ${ }^{h}$ & $0.50 * *$ & $0.57^{* *}$ & $0.63^{* *}$ & 0.08 & $0.84^{\star *}$ & -0.09 & -0.08 & -0.12 & \\
\hline FIM of rib eye & $0.57^{* *}$ & 0.07 & $0.79 * *$ & 0.09 & $0.79 * *$ & -0.07 & -0.06 & -0.09 & $0.84^{* *}$ \\
\hline
\end{tabular}

* $: P<0.05, * *: P<0.01$.

${ }^{a}$ DSMF ; detailed evaluation scores of meat firmness.

${ }^{b}$ FATPER ; ratio of marbling area to rib eye area.

${ }^{\circ}$ O_COARSE of ribeye ; overall coarseness of marbling in rib eye.

a ${ }^{-}$COARSE of ribeye ; number of coarser marbling particles in rib eye.

e COARSE $1-5$ of ribeye ; coarseness of the $1-5$ th larger marbling particles in rib eye.

${ }^{\dagger}$ COARSE $1-10$ of ribeye ; coarseness of the 1-10th larger marbling particles in rib eye.

${ }^{9} \mathrm{M} \_$COARSE of ribeye ; coarseness of the largest marbling particle in rib eye.

${ }^{\mathrm{h}} \mathrm{NSF}$ of ribeye; number of small flecks of marbling.

i FIM of ribeye ; fineness index of marbling particles in rib eye.

Table 4 Correlation coefficients among image analysis traits of gap of the muscle bundles in M. trapezius and the detailed evaluation score of meat firmness

\begin{tabular}{|c|c|c|c|c|c|c|c|c|}
\hline Traits & $\mathrm{DSMF}^{\mathrm{a}}$ & GAPPER & $\begin{array}{c}\text { O_COARSE } \\
\text { of GAP }\end{array}$ & $\begin{array}{c}\text { N_COARSE } \\
\text { of GAP }\end{array}$ & $\begin{array}{l}\text { COARSE 1-5 } \\
\text { of GAP }\end{array}$ & $\begin{array}{l}\text { COARSE } 1-10 \\
\text { of GAP }\end{array}$ & $\begin{array}{c}\text { M_COARSE } \\
\text { of GAP }\end{array}$ & NSG \\
\hline GAPPER $^{b}$ & $-0.75^{* *}$ & & & & & & & \\
\hline O_COARSE of GAP & $-0.45^{* *}$ & $0.74^{* *}$ & & & & & & \\
\hline N_COARSE of GAP ${ }^{d}$ & -0.22 & $0.45^{* *}$ & $0.33^{*}$ & & & & & \\
\hline COARSE $1-5$ of GAPe & $-0.34^{*}$ & $0.64 * *$ & $0.93 * *$ & 0.22 & & & & \\
\hline COARSE 1-10 of GAP & $-0.34^{*}$ & $0.64^{* *}$ & $0.96 * *$ & 0.23 & $0.99 * *$ & & & \\
\hline M_COARSE of GAPg & $-0.30^{*}$ & $0.62 * *$ & $0.80 * *$ & 0.19 & $0.90 * *$ & $0.86 * *$ & & \\
\hline $\mathrm{NSG}^{\mathrm{h}}$ & $-0.64^{* *}$ & $0.74^{* *}$ & $0.57^{* *}$ & 0.27 & $0.39 * *$ & $0.41^{* *}$ & $0.37^{* *}$ & \\
\hline $\mathrm{FIG}^{\mathrm{i}}$ & $-0.64^{* *}$ & $0.74^{* *}$ & $0.57^{* *}$ & 0.27 & $0.39 * *$ & $0.41^{* *}$ & $0.37^{* *}$ & $1.00 * *$ \\
\hline
\end{tabular}

* $: P<0.05, * *: P<0.01$.

a DSMF ; detailed evaluation score of meat firmness.

${ }^{b}$ GAPPER ; ratio of gap of the muscle bundles in the object region $(3008 \times 2000$ pixels) on M. trapezius.

${ }^{\circ}$ O_COARSE of GAP ; overall coarseness of gap of the muscle bundles in the object region $(3008 \times 2000$ pixels $)$ on M. trapezius.

dN_COARSE of GAP; number of coarser gap of the muscle bundles in the object region $(3008 \times 2000$ pixels) on M. trapezius.

${ }^{e}$ COARSE 1-5 of GAP ; coarseness of the 1-5th larger gap of the muscle bundle in the object region $(3008 \times 2000$ pixels) on M. trapezius.

${ }^{\dagger}$ COARSE $1-10$ of GAP ; coarseness of the $1-10$ th larger gap of the muscle bundle in the object region $(3008 \times 2000$ pixels) on M. trapezius.

${ }^{9}$ M_COARSE of GAP ; coarseness of the largest gap of the muscle bundle in M. trapezius.

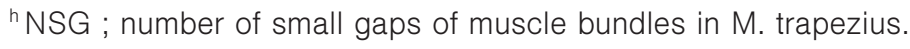

' $F I G$; fineness index of gap of muscle bundles in M. trapezius. 
析形質のうち, 筋束間隙数においては有意な相関関係は 見られなかったが，その他の 4 形質において 0.30 から -0.45 の負の相関係数が示された $(P<0.01 \sim 0.05)$. こ れは, 僧帽筋における大きい筋束間隙が多いほど, 肉の 締まりが悪いことを示している．また締まり詳細評価値 亡筋束間隙の細かさに関する 2 つの画像解析形質の間に おいて, ともに一0.64 と強い負の相関 $(P<0.01)$ が示さ れ, あらい筋束間隙に限らず, 細かい筋束間隙も多いほ ど締まりの評価が悪いことが示唆された。僧帽筋の筋束 間隙割合は, 筋束間隙数を除く筋束間隙のあらさおよび 細かさを示すいずれの形質とも強い正の相関関係 (0.62 $\sim 0.74: P<0.01)$ にあり, また, 筋束間隙のあらさ指数 と筋束間隙の細かさ指数との間に有意な正の相関 $(0.57$ : $P<0.01)$ が見られた.これは, 僧帽筋において, 目視 できる筋束間隙割合が高い場合，あらい筋束間隙だけで なく細い筋束間隙も多く存在することを示している.

\section{3. 画像解析形質を用いた肉の締まりの詳細評価値に 関する重回帰分析}

画像解析による客観的な肉の締まりの評価法を検討す るため, 肉の締まりの詳細評価値を従属変数とし, ロー ス芯における画像解析形質 (9 形質) および僧帽筋の筋 束間隙に関する画像解析形質 (8 形質) を説明変数候補 として，重回帰分析を行った。まず，説明変数候補に ロース芯における画像解析形質のみを用いた分析の結 果, 選択された变数はロース芯面積（回帰係数の符号: $+)$, 口ース芯の脂肪面積割合 $(+)$ およびロース芯にお けるあらさ粒子数 (一) であり, その決定係数は 0.56 で あった. 続いて, 説明変数候補にロース芯の画像解析形 質および僧帽筋における筋束間隙に関する画像解析形質 を用いた分析の結果, 選択された変数は僧帽筋における 筋束間隙割合 (一) およびロース芯における脂肪面積割 合 $(+)$ であり, その決定係数は 0.71 であった。ロース 芯の脂肪交雑に関する画像解析形質に, ウルトラマクロ レンズによって撮影された僧帽筋の筋束間隙に関する画 像解析形質を加えることにより, 締まりの詳細評価値の 推定精度が向上した.

枝肉の状態で判定される肉の締まりと筋束の状態に関 する研究報告はこれまでほとんど行われていないが，骨 格筋内の結合組織也筋線維の構成と肉のテクスチャとの 関連性については多数報告されている. Purslow（2005） は, 骨格筋内の結合組織の分布は筋束のサイズで決ま り，それらは肉の柔らかさの指標となると報告してお り, また, Sifre ら (2005) および Sifre-Maunier ら (2006) は, 筋組織の 2 つの主要な構成要素（筋原線維と結合組 織)の構造に関する研究は, 肉の柔らかさと硬度の予測 のために必要であると結論づけた．本研究で着目した筋 束間隙に関する画像解析形質は, 個々の筋束のサイズを 定量したものではないが, 食肉の望ましいテクスチャの 一要因である多汁性（沖谷 1996）に影響を与える肉の締
まりと強い相関を示したことから，筋束のサイズにも強 く関連していると推察される. 本研究では肉の締まりに ついてのみ調査を行ったが, 現行の格付において, 肉の きめについては, 骨格筋を形成する筋束の太さによって 判定されている（日本食肉格付協会 1996）ことから, 筋 束間隙に関する画像解析形質は, 肉のきめの客観的評価 にも有用な形質であると推察され, 今後, この点につい ても検討を重ねる必要があろう。また, 筋束の太さは骨 格筋の部位や品種によっても異なることが知られている (鈴木ら 1978). いずれの骨格筋も筋線維の太い白色筋お よび細い赤色筋から構成されているが，ホルスタイン種 では白色筋が多く含まれているのに対して, 黒毛和種で は赤色筋が多く含まれているという報告もある（岩元ら 1991). また, Ouali (1990) は, 白色筋の割合の高い骨格 筋において, 屠畜後の解糖速度が速いと報告した。解糖 と保水性の変化も関連（沖谷 1996）していることから, 骨格筋の部位の違いだけではなく, 品種によっても保水 性が大きくことなると推察される．また，本研究におい て僧帽筋のズーム画像を撮影するために用いたウルトラ マクロレンズは, 被写界深度が浅く, 撮影には細心の注 意が必要であるため, 今回のような実験室における使用 は可能であるが，枝肉市場などにおいて一般出荷牛に用 いるには相応しくない，肉の締まりの客観的評価の精度 向上に向け，デー夕の収集方法を検討した上で，本研究 における手法がホルスタイン種以外の品種においても有 用であるか検討する必要がある。

$$
\text { 謝辞 }
$$

本研究の一部は先端技術を活用した農林水産研究高度 化事業委託事業「光学的手法による和牛肉品質の評価技 術とその応用：No. 1674 代表研究者：入江正和」におけ る研究費を使用して行われたものであり，ここに感謝の 意を表する.

\section{文献}

（社）中央畜産会. 2000. 日本飼養標準・肉用牛.（社)中央畜産 会, 東京.

浜崎陽子, 口田圭吾, 日高 智, 島田謙一郎, 関川三男, 丸山 新. 2005. 画像解析によるホルスタイン種を用いた BMS ナ ンバー推定法ならびに異なる横断面の脂肪交雑特徴量の比 較。日本畜産学会報 76, 431-437.

長谷川未央, $\square$ 田圭吾, 佃 秀雄, 加藤浩二, 鈴木三義, 三好俊 三. 2004. 脂肪交雑粒子のあらさおよび胸最長筋の形状に 関する画像解析值を用いたBMS ナンバーの推定. 日本畜 産学会報 75, 53-60.

岩元久雄, 尾野喜孝, 後藤貴文, 西村正太郎, 中西良孝, 梅津頼 三郎, 高原 斉. 1991. 黒毛和種, 褐毛和種およびホルス夕 イン種の去勢雄牛間での筋線維型構成に関する比較検討. 日本畜産学会報 62，674-682.

口田圭吾, 栗原晃子, 鈴木三義, 三好俊三。1997。画像解析によ るロース芯断面内脂肪割合の正確な算出法の開発. 日本畜 産学会報 68, 853-859. 
$\square \boxplus$ 圭吾, 大澤剛史, 堀 武司, 小高仁重, 丸山 新. 2006. 画 像解析による牛枝肉横断面の評価とその遺伝. 動物遺伝育 種研究 34, 45-52.

$\square \boxplus$ 圭吾, 鈴木三義, 三好俊三. 2002. 画像解析による牛胸最長 筋脂肪交雑粒子のあらさに関する評価法の検討。日本畜産 学会報 73, 9-17.

（社）日本食肉格付協会. 2007. 牛枝肉格付情報平成 18 年 4 月 平成 19 年 3 月版. CD-ROM.（社) 全国肉用牛振興基金協 会, 東京.

（社）日本食肉格付協会. 1996. 牛・豚・枝肉部分肉取引規格解 説書. 日本食肉格付協会, 東京.

沖谷明紘. 1996. 肉の科学. 初版. pp. 59-87. 朝倉書房, 東京.

Ouali A. 1990. Meat tenderization : possible causes and mechanisms. A review. Journal of Muscle Foods 1, 129-165.

Purslow PP. 2005.Intramuscular connective tissue and its role in meat quality-review. Meat Science 70, 435-447.

SAS institute Inc. 1985. SAS User's guide: Statistic. Ver 5 edn. pp. 433-506. SAS Institute Inc. Cary, NC.
Sifre L, Berge P, Engel E, Martin JF, Bonny JM, Listrat A. 2005. Influence of the spatial organization of the perimysium on beef tenderness. Journal of Agricultural and Food Chemistry 53, 8390-8399.

Sifre-Maunier L, Taylor RG, Berge P, Culioli J, Bonny JM. 2006. A global unimodal thresholding based on probabilistic reference maps for the segmentation of muscle images. Image and Vision Computing 24, 1080-1089.

白仁田和彦, 宮島恒晴, 瀧山龍三. 1996. 画像処理とニューラル ネットワークによる牛枝肉の等級判定. 電子情報通信学会 技術報告 NC96-55, 41-46.

鈴木 惊, 大和田修一, 玉手英雄. 1978. 黒毛和種とホルスタイ ン種の骨格筋における筋線維内脂肪滴の有無と各筋線維型 の割合と太さ。日本畜産学会報 49, 262-269.

高橋健一郎, 口田圭吾, 堀 武司, 波 通隆, 小高仁重. 2006. ミラー型撮影装置を用いた肉用品種における脂肪交雑形状 特性の比較. 日本畜産学会報 77, 501-507. 


\title{
Investigation of objective evaluation method for meat firmness by computer image analysis of Holstein steers
}

\author{
Yoko HAMASAKI ${ }^{1}$, Toshiro SAITO², Yukinobu SATO², Junichi NAGATSUKA ${ }^{3}$ and Keigo KUCHIDA \\ 1 Obihiro University of Agriculture and Veterinary Medicine, Obihiro 080-8555, Japan \\ ${ }^{2}$ Hokkaido Animal Research Center, Shintoku, Hokkaido 081-0038, Japan \\ ${ }^{3}$ Research \& Development Section Technical Research Institute of Livestock and Grassland Science, \\ HOKUREN Federation of Agricultural Cooperatives, Kunneppu, Hokkaido 099-1421, Japan \\ Corresponding : Keigo KUCHIDA (fax : +81 (0) 155-49-5462, e-mail : kuchida@obihiro.ac.jp)
}

The firmness of meat is deeply related to the quality and palatability of the meat, and has a large economic impact. However, it is difficult to perform a stable subjective evaluation of meat firmness because there is no objective standard model for judging. The purpose of this study was to investigate the objective evaluation method for meat firmness by using computer image analysis. Generally, the evaluation of the meat firmness is visually graded into 5 scores (1: poor -5 : fairly good). In this study, the meat firmness was minutely evaluated into 15 scores by the expert grader of the meat quality evaluation for 51 Holstein steers. The digital images of the carcass cross section were taken between the 6th and 7th ribs by the mirror-type photographing equipment, and the macro images of $\mathrm{M}$. trapezius at the 6th and 7th ribs were taken with the digital camera attached with an ultra macroscopic lens. Using the digital images of carcass cross section, the ratio of marbling area to rib eye area (FATPER) as well as traits for marbling particles were obtained by image analysis. Also, in this study, the boundary division between muscle bundles on the zoom image of M. trapezius, was determined as a muscle bundle gap. The ratio of gap of the muscle bundles occupied in the object region of $3008 \times 2000$ pixels (GAPPER) and traits for the gap of the muscle bundles were also calculated for the macro images of M. trapezius. The correlation coefficient between detailed evaluation score of the meat firmness and FATPER was highly significant $(r=0.73, P<0.01)$. On the other hand, the correlation coefficient between GAPPER and the detailed evaluation score for the meat firmness was -0.75 $(P<0.01)$. Multiple regression analysis was conducted in order to evaluate the firmness of the meat by objective image analysis variables. Selected variables of the multiple regression equation were GAPPER with the negative regression and FATPER with the positive regression $\left(R^{2}=0.71, P<0.01\right)$. Results of this study showed that the meat firmness was highly related to the condition of the muscle bundles and the possibility of the objective evaluation by means of image analysis for the meat firmness.

Nihon Chikusan Gakkaiho 80 (1), 47-54, 2009

Key words : Holstein steer, image analysis, meat firmness, M. trapezius. 